\title{
ANÁLISE DISCURSIVA DE EDITORIAIS SOBRE O APOIO AO GOLPE MILITAR DE 1964
} Antônio Felipe Aragão dos Santos é professor de Língua e Literatura Latina e doutorando em Linguística na Universidade Federal do Ceará
- UFC.

E-mail: felipearagaos@hotmail.com

\begin{abstract}
Resumo
Este artigo faz uma análise crítica do discurso de dois editoriais publicados pelo jornal $O$ Globo referentes a dois momentos importantes da história do Brasil: o golpe militar de 1964 e as manifestações ocorridas em junho de 2013 no país. Utilizando-se dos Estudos Críticos do Discurso de Dijk, da Análise Crítica do Discurso de Fairclough e dos trabalhos sobre o discurso midiático de Chomsky, identificamos algumas estratégias utilizadas pelos editoriais tanto para manipular o público leitor quanto para persuadir.
\end{abstract}

\begin{abstract}
This article makes a critical discourse analysis of two editorials published by $\mathrm{O}$ Globo newspaper referring to two important moments in the history of Brazil: the military coup of 1964 and the manifestations that took place in June 2013 in the country. Utilizing Critical Studies of Discourse of van Dijk, of Critical Discourse Analysis of Fairclough and the studies about the media discourse of Chomsky, we identified some strategies used by both editorials to manipulate the public as to persuade the reader.
\end{abstract}

\section{Introdução}

A análise do discurso é um campo de pesquisa cujo objetivo é compreender a produção social de sentidos, realizada por sujeitos históricos, por meio da materialidade das linguagens. Cada vez mais, a mídia ${ }^{1}$ tem-se tornado objeto privilegiado das investigações dos analistas de discurso.

Este trabalho buscou fazer uma análise de dois editoriais publicados pelo jornal $O$ Globo. O primeiro, publicado no dia 02 de abril de 1964, marco inicial do regime militar no Brasil, e o segundo, no dia 31 de agosto de 2013, dois meses depois das grandes manifestações ocorridas a nível nacional.

Para se entender o contexto em que os dois editoriais foram publicados, fazemos primeiramente um rápido estudo sobre as manifestações ocorridas durante o mês de junho de 2013 no Brasil, pois julgamos ser uma das causas da publicação do editorial do dia 31 de agosto de 2013 do jornal $O$ Globo. Posteriormente, trazemos um estudo sobre o contexto histórico-político do Brasil à época em que fora publicado o editorial de 02 de abril de 1964 do mesmo jornal. Após o estudo do contexto de produção dos dois editoriais, partimos para uma rápida exposição do referencial teórico utilizado para a análise destes textos, buscando relacioná-los a outros editoriais de jornais de grande circulação como $O$ Estadão e o Folha de S. Paulo.

Como metodologia para a análise dos dados, utilizamos as contribuições Fairclough (2003) no campo da Análise Crítica do Discurso (ACD), especificamente no estudo do discurso como fator constitutivo e constituinte da sociedade. Buscamos em Dijk (2012; 2008), no âmbito dos Estudos Críticos do Discurso (ECD), parâmetros para a compreensão do

\footnotetext{
${ }^{1}$ Utilizamos o termo mídia como os meios de comunicação de massa (imprensa, televisão, rádio, internet, teatro, cinema, dança etc.). Curiosamente, trata-se da adoção, no Brasil, da pronúncia inglesa para a palavra latina media (sem acento, plural de medius, que quer dizer "meio"), retirada da expressão mass media que, por sua vez, os ingleses extraíram da locução latina media communicationis (meios de comunicação). Em suma, os ingleses escrevem media e pronunciam mídia.
} 
discurso produzido pelas esferas responsáveis pela veiculação de informação em larga escala. Ter acesso ao ambiente em que os editoriais foram produzidos não é uma tarefa fácil, uma vez que as reuniões que acontecem nos altos escalões de jornais e revistas de grande circulação tratam de assuntos delicados como a defesa de um ponto de vista político.

Em nossas considerações finais, trazemos a importância dos estudos da Análise Crítica do Discurso (ACD) e dos Estudos Críticos do Discurso (ECD) como ferramentas para análise de textos, principalmente os da mídia, e compreensão das estratégias de manipulação utilizadas por aqueles que participam ativamente da elaboração destes textos.

\section{1) As manifestações de junho}

Em 2013, mais especificamente durante o mês de junho, ocorreram várias manifestações populares por todo o Brasil. As manifestações surgiram para contestar os aumentos nas tarifas de transporte público (daí também serem chamadas de "Manifestações dos 20 centavos"), tendo lugar principalmente nas principais capitais, ganhando enorme apoio popular após a forte repressão policial contra as passeatas.

Atos semelhantes rapidamente começaram a se proliferar em diversas cidades do Brasil e do exterior em apoio aos protestos, passando a abranger uma grande variedade de temas, como os gastos públicos em grandes eventos esportivos internacionais, a má qualidade dos serviços públicos e a indignação com a corrupção política em geral. Os protestos geraram grande repercussão nacional e internacional.

Em São Paulo, houve uma represália policial que causou muitos feridos, incluindo vários jornalistas, que gradualmente mudaram o discurso de forte crítica àqueles que protestavam $^{2}$. Em 13 de junho, houve mais de 300 pessoas detidas, mais de 100 delas "detidas para averiguação", prática comum em ditaduras, já que não há flagrante, e muitas delas foram detidas por portarem vinagre, substância legalmente permitida no Brasil ${ }^{3}$. Devido à violência, comportamento da mídia, e outros fatores, depois desse dia houve um crescimento exponencial do número de participantes nas manifestações.

Alguns fatores contribuíram para que um dos alvos dos protestos se direcionasse explicitamente para a Rede Globo. É fato que tanto a forma como a emissora cobriu as manifestações (principalmente no início) quanto a divulgação pública (menos pela própria emissora) da dívida milionária da Rede Globo com a Receita Federal ${ }^{4}$ contribuíram para que, em meio a tantas reivindicações, o povo não deixasse de fora as críticas à TV de maior audiência do país. Porém, mais do que uma relação única com a Rede Globo, as manifestações guardavam algo maior: uma insatisfação popular com a ausência de diversidade e pluralismo na mídia brasileira, guardavam, acima de tudo, uma necessidade

\footnotetext{
${ }^{2}$ A utilização do termo "minoria" ao se referir aos manifestantes que depredavam bancos passou a ser frequente no discurso da mídia.

${ }^{3}$ Dados obtidos no endereço eletrônico http://memoria.ebc.com.br/agenciabrasil/noticia/2013-06-13/mais-de100-pessoas-detidas-para-averiguacao-em-protesto-contra-aumento-da-tarifa-em-sp, acessado em 15/04/2014.

4 A TV Globo já foi anteriormente cobrada em mais de R $\$ 600$ milhões por suposta sonegação fiscal na compra dos direitos de retransmissão da Copa do Mundo de 2002, cujo processo acabou extraviado. A Receita Federal informou o extravio dos autos do procedimento fiscal, que gerou investigação paralela para identificar os envolvidos. A investigação resultou em ação criminal contra uma servidora da Receita Federal, condenada a 4 anos e 11 meses de prisão.
} 
sentida pelo povo de regras claras que garantissem maior democracia no rádio e na televisão. Cerca de $70 \%$ das verbas publicitárias repassadas aos principais veículos de comunicação durante os 18 meses do governo Dilma, a Rede Globo, sozinha, arrematou 35\% destes recursos. Além disso, a empresa de comunicação detém poder de veto na definição dos canais da NET e da SKY, que possuem $80 \%$ do mercado midiático nacional ${ }^{5}$.

A democratização, diversidade e pluralismo nos veículos de informação foram então temas de protestos por todo o Brasil, denunciando a monopolização dos meios de comunicação e a tentativa de manipulação da massa por meio do que é publicado. Um episódio que retrata bem a aversão contra a Rede Globo durante as manifestações aconteceu no dia 17 de junho de 2013. Em São Paulo, Caco Barcellos e sua equipe da Rede Globo foram expulsos do protesto por cerca de 100 manifestantes que gritavam "Fora Globo", "Central Globo de Mentiras" e "manipulador". O jornalista tentou continuar acompanhando o protesto, mas os manifestantes gritavam contra a Rede Globo toda vez que a câmera era ligada ${ }^{6}$.

Outras emissoras de televisão também foram alvos das manifestações. No dia 18 de junho de 2013, em São Paulo, um carro gerador da Rede Record que fazia transmissão ao vivo foi incendiado pelos manifestantes logo após a equipe ser apedrejada. No dia 20 do mesmo mês, no Rio de Janeiro, foi a vez de um carro do $S B T$ ser incendiado pelos manifestantes ${ }^{7}$.

Diante de tudo isso, um período de perseguições e manipulações veio à tona durante as manifestações, a ditadura instalada em 1964 no país, que duraria 20 anos. Mais uma vez, a Rede Globo teve um papel importante na relação do regime militar com a atual conjuntura das manifestações.

Foi em um ambiente de fortes manifestações e reivindicações contra a corrupção e programação por parte dos veículos de informação da mídia que o jornal $O$ Globo lançou o editorial confessando o "erro" em ter apoiado o golpe militar de 1964.

\section{2) Ressurge a democracia}

Com o título que dá nome ao presente item deste artigo, o jornal $O$ Globo lançava seu editorial do dia 02 de Abril de 1964 de apoio ao golpe de estado dado pelos militares ao destituírem João Goulart da presidência da República.

Quando se pretende fazer um estudo sobre um texto que representa uma coletividade, como uma carta de repúdio elaborada por determinada instituição, um editorial que expresse a opinião de uma revista ou jornal, ou mesmo um discurso do mais alto representante da igreja católica, surgem alguns problemas metodológicos assinalados por van Dijk (2008).

Podemos analisar criticamente uma notícia ou um editorial público, um livro didático ou uma interação em sala de aula, a propaganda de um partido político ou a publicidade de uma empresa, mas raramente teremos acesso ao tipo de interação discursiva que ocorre no topo: uma reunião da cúpula do governo, a reunião editorial de um jornal, uma reunião dos líderes de um partido político ou as deliberações dos diretores de uma empresa. (ibid., p. 22)

\footnotetext{
${ }^{5}$ Informações obtidas no site http://www.cartacapital.com.br/politica/globo-concentra-verba-publicitaria-federal acessado em 11/10/2014.

6 Informações obtidas no endereço eletrônico http://ultimosegundo.ig.com.br/brasil/sp/2013-06-17/cacobarcellos-e-hostilizado-por-manifestantes-em-sao-paulo.html acessado em 15/04/1014.

7 Dados obtidos no site http://www1.folha.uol.com.br/ilustrada/2013/06/1298617-globo-suspende-transmissaode-jogo-e-novelas-para-cobrir-protestos.shtml acessado em 15/04/2013.
} 
De fato, o que analisamos aqui é o produto final, o texto. Não foi propósito deste artigo se debruçar sobre o processo de construção dos editoriais em questão, mas, sim ater-se aos mecanismos linguísticos que contribuem para gerar efeitos persuasivos, como assinala Dijk (2008):

O poder discursivo costuma ser direta ou indiretamente persuasivo e, portanto, exibe justificativas, argumentos, promessas, exemplos e outros instrumentos retóricos que aumentam a probabilidade de os receptores formarem as representações mentais desejadas. Uma estratégia crucial quando se trata de disfarçar o poder é convencer as pessoas sem poder de que elas praticaram as ações desejadas em nome de seus interesses. (ibid., p. 84)

O título "Ressurge a democracia" dá uma ideia de que o período anterior a 02 de abril de 1964 representou um sistema de governo não democrático. A utilização do verbo ressurgir indica que já houve um período democrático no Brasil, sendo substituído por outro sistema de governo para finalmente, em 1964, ressurgir $^{8}$. O texto deixa explícito que foi

"graças à decisão e ao heroísmo das forças armadas, que obedientes a seus chefes demonstraram a falta de visão dos que tentavam destruir a hierarquia e a disciplina", o Brasil livrou-se do governo irresponsável, que insistia em arrastá-lo para rumos contrários à sua vocação e tradição?

Percebe-se a utilização de verbos na terceira pessoa do plural sem a identificação individual dos agentes participantes do movimento de "Salvação". Por ser uma ação que foi contra a Constituição do país, o jornal buscou não identificar os militares que participaram do golpe. O que há são referências a uma coletividade, "Forças Armadas", "bravos militares". O jornal sabe que a ação dos militares foi ilegal, mas devido à atual conjuntura política do país, não haveria alternativa, de acordo com o jornal. $\mathrm{O}$ editorial ressalta que o movimento de "salvação" não foi um ato advindo apenas das forças armadas ou mesmo de partidos políticos, pois "dele participaram todos os setores conscientes da vida política brasileira". Todos unidos com o "mesmo intuito redentor". Em outras palavras, o "movimento vitorioso não pertencia a ninguém", mas a todos.

O editorial chega a citar o artigo 176 da CF (Constituição Federal) sobre as forças armadas, ressaltando a sua organização com base na hierarquia e na disciplina e sob a autoridade do presidente da república. Uma vez ignoradas a disciplina e a hierarquia, uma atitude contra a própria autoridade (o presidente) se fazia necessária.

No momento em que o Sr. João Goulart ignorou a hierarquia e desprezou a disciplina de um dos ramos das Forças Armadas, a Marinha de Guerra, saiu dos limites da lei, perdendo, consequentemente, o direito a ser considerado como um símbolo da legalidade, assim como as condições indispensáveis à Chefia da Nação e ao Comando das corporações militares. Sua presença e suas palavras na reunião

\footnotetext{
${ }^{8}$ O país já havia sofrido um golpe de estado implantado pelos militares. Nesta ocasião, ocorreu a proclamação da república, dando início à chamada República da Espada, quando os militares lideraram o país politicamente entre os anos de 1889 a 1894. Assim que a monarquia foi derrubada, o governo provisório do marechal Deodoro da Fonseca guiou as decisões tomadas no Brasil. Muitos consideram a República da Espada o primeiro período ditatorial no Brasil. As figuras chaves da época foram os marechais Floriano Peixoto e Deodoro da Fonseca. A repressão era forte contra os levantes populares e os simpatizantes de Dom Pedro II.

9 O Editorial de 02 de abril de 1964 foi obtido por meio do site http://acertodecontas.blog.br/politica/editorialdo-jornal-o-globo-de-2-de-abril-de-1964-celebrando-o-golpe-militar/ acessado em 16/04/2014.
} 
realizada no Automóvel Clube, vincularam-no, definitivamente, aos adversários da democracia e da lei ${ }^{10}$.

Uma mudança radical na forma de governo poderia causar medo na população. Dessa forma, o discurso na maioria dos veículos de informação foi que o país estaria se dirigindo a um regime totalitário. Ao analisar o discurso da mídia, Chomsky afirma que os meios de comunicação têm de instigar as pessoas quando a proposta daqueles que estão no poder é "se envolver em aventuras externas, mortes e tortura" (CHOMSKY, 2013, p. 31). O regime militar que estava sendo imposto precisava de apoio da população para quaisquer ações que viesse a tomar para manter a segurança e a democracia no país. A mídia desempenhou bem o papel de manipulação.

O mesmo apagamento dos sujeitos individuais não é visto quando o jornal se refere àquele que seria o causador da desestruturação das forças armadas. O presidente João Goulart passou a ser considerado por grande parte dos veículos da informação como uma ameaça à legalidade. Como vimos no parágrafo acima, a mídia, por interesses próprios e privados, produziu discursos com o objetivo de levar medo à população e aceitar as medidas tomadas pelos militares como sendo necessárias. O poder de manipulação do discurso da mídia é bastante estudado por Chomsky.

Você assusta e aterroriza a população, intimidando-a a tal ponto que ela fica com medo de viajar e se encolhe apavorada. Em seguida você conquista uma magnífica vitória sobre Granada, Panamá ou algum outro exército indefeso do Terceiro Mundo que se pode triturar num piscar de olhos - que foi exatamente o que aconteceu. Isso dá uma sensação de alívio. Fomos salvos no último minuto. Esta é uma das maneiras de evitar que o rebanho desorientado preste atenção no que realmente está acontecendo ao seu redor, uma maneira de mantê-lo distraído e sob controle. (ibid., p. 45)

Relacionando a citação acima à conjuntura sociopolítica do Brasil no período em análise, temos que o país estaria em guerra com as ideias comunistas que estariam vindo por meio do presidente da república, conhecido por simpatizar-se com o comunismo. O "rebanho desorientado" seria a grande parte da população que não se conscientizava do que estaria por trás do golpe ${ }^{11}$.

Não defendemos a ideia de que os leitores do editorial em análise tenham desempenhado um papel passivo no que diz respeito ao discurso veiculado. Baseando-nos em pesquisas empíricas no campo da comunicação, feitas desde a década de 1960, temos que o receptor dificilmente assimila as mensagens diretas e subliminares de uma mensagem conforme proposto pelo enunciador (McQUAIL, 2005). As pesquisas com receptores são unânimes ao afirmar que as pessoas que consomem produtos midiáticos são totalmente ativas

10 No dia 13 de março de 1964, João Goulart realizou um comício na Central do Brasil, região central do Rio de Janeiro, para defender as reformas de base propostas por seu governo. Cerca de 200 mil pessoas acompanharam o discurso que foi encerrado com as seguintes palavras: "Não apenas pela reforma agrária, mas pela reforma tributária, pela reforma eleitoral ampla, pelo voto do analfabeto, pela elegibilidade de todos os brasileiros, pela pureza da vida democrática, pela emancipação, pela justiça social e pelo progresso do Brasil". <http://www.ebc.com.br/cidadania/2014/03/discurso-de-jango-na-central-do-brasil-em-1964>. Acessado em: 16 abr. 2014.

${ }_{11}$ Como a interferência norte-americana no golpe. No ano de 1963, os EUA já estavam empenhados em apoiar os círculos de oposição brasileira, inclusive os que defendiam como solução o golpe militar. 
no processo de interpretação e de crítica em relação às mensagens divulgadas pelos meios de comunicação, não importando as diferenças econômicas e de escolaridade. Cada um de nós enxerga as mensagens jornalísticas e atribui um sentido segundo nossas trajetórias sociais singulares.

Fazendo uma diferenciação entre persuasão e manipulação, temos que o editorial de apoio ao golpe trata-se de uma tentativa de manipulação, se considerarmos o público leitor como incapaz de identificar as reais intenções do golpe.

\begin{abstract}
A diferença crucial neste caso é que na persuasão os interlocutores são livres para acreditar ou agir como desejarem, dependendo se eles aceitam ou não os argumentos do persuasor; já na manipulação aos receptores é dado, tipicamente, um papel mais passivo: eles são vítimas da manipulação. Essa consequência negativa do discurso manipulador ocorre tipicamente quando os receptores são incapazes de entender as intenções reais ou de perceber todas as consequências das crenças e ações defendidas pelo manipulador. (DIJK, 2008, p. 235).
\end{abstract}

Acreditamos que os discursos persuasivos se tornaram cada vez mais manipuladores com o aumento potencial de uma opinião pública massificada que foi objeto de apropriação no campo político (poder), comercial (lucro), midiático (concorrência). Acreditamos, também, que os indivíduos que vivem em sociedade têm necessidade do espetáculo que colocam em cena as forças do Bem e do Mal. Tal necessidade é encontrada nas sociedades mais antigas e nas mais primitivas através de mitos e lendas. Em nossas sociedades modernas, isso se dá através da literatura, do cinema fantástico (Guerra nas estrelas) e dos diferentes espetáculos espelhos nos quais as populações encontram sua razão de ser identitária. O editorial em análise põe explicitamente as forças armadas no lado do Bem, enquanto que aqueles que estariam ao lado do presidente João Goulart (incluindo aí as ideias comunistas) representavam o Mal.

A solução encontrada consistiu em propor medidas que deveriam reparar o mal existente e, ao mesmo tempo, construir a imagem daquele que se apresenta como um salvador : as forças armadas, aparecendo de forma tão credível, construindo para si um ethos de potência e de salvador da nação.

Estas condições de dramatização devem ser consideradas por seu efeito emocional e não por seu valor argumentativo. É por isso que podemos falar de manipulação pela encenação do sofrimento das vítimas, do medo de ameaças potenciais, da agitação dos bodes expiatórios (imigração) e dos complôs (lobby judaico), conservação da vergonha (o declínio do país) e da culpabilidade (aquecimento do planeta), e tudo isso para provocar um elã coletivo. Isto satisfaz o ritual do sacrifício coletivo, que tem por efeito provocar uma catarse social através de um processo de reconciliação/reparação em torno de uma mesma vítima expiatória que deve fazer reviver o homem novo. (CHARAUDEAU, p. 72, 2010)

Consideramos o texto de reconhecimento do erro por ter apoiado o golpe como persuasivo (seguindo a definição dada por Dijk). O contexto sócio-histórico é outro, a Rede Globo passa a ser alvo das manifestações advindas de grupos ligados direta ou indiretamente aos mesmos ideais combatidos durante o golpe de 1964.

Manipular pessoas envolve manipular suas mentes, ou seja, as crenças das pessoas, tais como seus conhecimentos, suas opiniões e suas ideologias, os quais por sua vez controlam suas 
ações. Constatamos, entretanto, que há muitas formas da influência mental baseadas no discurso, tais como informar, ensinar e persuadir, o que também modela ou muda os conhecimentos e as opiniões das pessoas. (ibid., p. 240)

O crescimento das ideias comunistas na década de 1960, influenciado pela disputa pela hegemonia política e econômica entre Estados Unidos e União Soviética, fez com que os EUA interferissem direta e/ou indiretamente na política de vários países da América, tendo o Brasil como um aliado na luta contra as ideias comunistas. A mídia funcionou como meio para que as elites capitalistas divulgassem ideias contrárias ao comunismo, levando, inclusive, o medo à população, uma vez que se referiam ao comunismo como uma ameaça.

Outro ponto interessante a ser analisado no editorial de 1964 é a relação do golpe dado pelos militares à "providência divina". A ligação dos militares aos poderes inexplicáveis, divinos pode ser bem entendida ao considerar que o país era e continua sendo predominantemente católico. Dessa forma, todos estavam unidos para o ressurgimento da democracia, Forças Armadas, o Povo e Deus, quem mais poderia endossar a ação dos militares do que estes agentes? Vemos, então, que a utilização do termo "divino" não é por acaso.

O uso de variantes lexicais específicas pode também ter efeitos de "enquadre" muito diferentes na ativação de atitudes e ideologias políticas e, portanto, na construção de modelos de evento. As elites podem, então, usar termos específicos no discurso da mídia ou da política para influenciar a opinião pública. (ibid., p. 229)

Diante do que foi visto até aqui, vemos que o editorial de 1964 buscou construir um contexto que pudesse justificar as ações tomadas pelas forças armadas. Ao falar de contexto, não estamos nos referindo apenas à situação social objetiva. Assim como Dijk (2012), entendemos o contexto como um construto dos participantes, a respeito das propriedades que para eles são relevantes em tal situação, isto é, modelos mentais (ibid., p. 87).

Ao se deparar com o editorial, o leitor, formulará um modelo mental sobre a atual situação política do país. Este modelo de contexto é um tipo especial de modelos da experiência do dia a dia, representados na memória episódica dos participantes do discurso. Dessa forma, o editorial constrói (muito provavelmente coletivamente) um modelo de contexto, ressaltando o "heroísmo das forças armadas", de "providência divina", de um "tão grande favor" prestado pelos militares, de superação "da grave crise" com o intuito de fazer com que os seus leitores também produzam o mesmo modelo de contexto.

A tese crucial de um modelo mental é que, além da representação do sentido de um texto, os usuários da língua também constroem modelos mentais dos eventos que são assunto desses textos, isto é, a situação que eles têm como denotação ou referência - daí o nome de "modelos de situação". (ibid., p.87)

O medo, o apelo às instâncias divinas e a disposição linguística dos enunciados (como o apagamento de determinados sujeitos, por exemplo) são ferramentas de que a mídia se utiliza para, como diz Dijk, manipular mentes. 


\section{3) "Apoio editorial ao golpe de 64 foi um erro"}

Pouco tempo depois das manifestações de junho, em meio a um ambiente de forte apelo à valorização e democratização da saúde, educação, justiça, pluralidade de informação advinda das emissoras de televisão, rádio e jornais impressos etc., o jornal $O$ Globo lança, no dia 31 de agosto de 2013, às 17 horas, um editorial com o seguinte título: "Apoio ao golpe de 64 foi um erro".

No início do editorial, podemos ver um trecho que mostra bem a tentativa de, por meio de seu discurso, se aproximar da fala de boa parte de pessoas durante as manifestações de junho do mesmo ano. As Organizações Globo sabiam que eram um dos alvos dos manifestantes e, numa tentativa de autoconfissão, a instituição buscou sair do papel de vilão e responsável por parte das mazelas do país para um papel de réu confesso, que estaria reconhecendo os seus erros e aprendendo com eles. Vejamos o trecho que dá início ao editorial:

A consciência não é de hoje, vem de discussões internas de anos, em que as Organizações Globo concluíram que, à luz da História, o apoio se constituiu um equívoco.

RIO - Desde as manifestações de junho, um coro voltou às ruas: "A verdade é dura, a Globo apoiou a ditadura". De fato, trata-se de uma verdade, e, também de fato, de uma verdade dura.

Podemos destacar algumas partes do trecho acima para que possamos compreender um dos principais objetivos do editorial em análise. Comecemos pelo trecho "A consciência não é de hoje". Percebe-se que, ao contrário do que muitos leitores poderiam imaginar, o presente editorial (com todo o seu discurso veiculado) não foi publicado com o objetivo (pelo menos não explicitamente) de reduzir o impacto que as Organizações Globo estavam sofrendo. Em outras palavras, a consciência de que a decisão de apoiar o golpe militar fora errada não surgiu com as manifestações, pois já era fruto "de discussões internas de anos". A utilização da palavra "interna" é bem sugestiva. Por serem internas, estas discussões não chegavam ao público leitor, daí o seu desconhecimento.

Podemos ver uma mudança de postura discursiva quando comparamos o editorial de 1964 com o de 2013. É comum entre os discursos manipuladores ou mesmo persuasivos lançarem intencionalmente uma falsa informação ou denunciar como falsa uma informação que circula na sociedade, para que a opinião pública julgue os acontecimentos de uma determinada maneira ou aja numa determinada direção. $O$ Globo admite a culpa, ato que demonstra certa submissão frente aos fortes protestos ocorridos em 2013.

A confissão de culpa, bem como o discurso de impossibilidade de prever o futuro são ferramentas bastante utilizadas quando se trata de defesa contra atos reprováveis publicamente. Em um discurso de defesa proferido pelo até então senador Demóstenes Torres no dia 29 de maio de 2012 no Conselho de Ética do Senado, ao justificar relações financeiras com Carlos Cachoeira, disse "Eu não tinha a lanterna na popa”. Vemos que Demóstenes, ao 
trazer esta metáfora, busca explicar a sua falta de informações a respeito de Carlos Cachoeira $^{12}$.

Outra parte importante do trecho em análise é a expressão "à luz da história". Percebese que o apoio dado aos militares teria sido justificável pelo atual contexto do país. Naquele momento específico, não haveria outra opção mais aconselhável do que defender o golpe. Porém, quando se faz um estudo tomando por base as décadas que vieram depois do golpe, a decisão se mostrou equivocada. O jornal confessa que de fato apoiou o golpe, e esta decisão está repercutindo atualmente na consciência daqueles que "à luz da história" perceberam que o apoio foi um erro, e este mesmo erro trata-se de uma "verdade dura".

Segundo o editorial em análise, esta "verdade dura" não deve estar restrita ao jornal $O$ Globo. Percebe-se, no trecho abaixo, a tentativa de diminuir o foco quando se trata do apoio dado ao golpe. Há, então, uma tentativa de compartilhar o erro cometido, uma vez que outras instituições também apoiaram o golpe.

O GLOBO, de fato, à época, concordou com a intervenção dos militares, ao lado de outros grandes jornais, como "O Estado de S.Paulo", "Folha de S. Paulo", "Jornal do Brasil" e o "Correio da Manhã", para citar apenas alguns. Fez o mesmo parcela importante da população, um apoio expresso em manifestações e passeatas organizadas em Rio, São Paulo e outras capitais.

A utilização da palavra "dura" passa ao leitor a ideia de que aqueles que compõem o jornal têm de carregar uma culpa que, à luz da história, seria desculpável. A seleção de palavras nos discursos não é feita à toa, pois segundo Dijk (2012, p.238),

é por meio das palavras que usam, os falantes mostram suas identidades sociais, suas relações enquanto participantes, sua adaptação à audiência, seu estado de espírito, suas emoções, seus valores, suas opiniões e atitudes, seus propósitos, seu conhecimento e os tipos de situações (in)formais ou institucionais em que estão falando ou escrevendo.

Em 07 de outubro de 1984, portanto mais de 20 anos após o golpe, período suficiente para julgar se a ação de defender os militares foi ou não correta, $O$ Globo lançava um editorial que continuava apoiando as ações tomadas em 1964. Eis um trecho:

"Temos permanecido fiéis aos seus objetivos [da revolução], embora conflitando em várias oportunidades com aqueles que pretenderam assumir a autoria do processo revolucionário, esquecendo-se de que os acontecimentos se iniciaram, como reconheceu o marechal Costa e Silva, 'por exigência inelutável do povo brasileiro'. Sem povo, não haveria revolução, mas apenas um 'pronunciamento' ou 'golpe', com o qual não estaríamos solidários"

\footnotetext{
${ }^{12}$ A popa ou ré é a seção traseira de uma embarcação, sendo tecnicamente definida como a área construída entre o painel de popa e as alhetas da embarcação. Para permitir maior proximidade à zona de manobra, ao mesmo tempo em que aproveitava a zona mais abrigada do navio e menos sujeita a balanço do navio, a popa passou a ser a localização preferida para instalação dos aposentos do capitão e dos seus oficiais. Quem não possui a lanterna na popa ${ }^{12}$ estaria, assim, impossibilitado de ter uma boa visão de onde os caminhos poderiam ser traçados.
} 
Nosso objetivo não foi fazer um estudo dos vários editoriais de apoio ao golpe publicados em jornais da época. Porém, podemos fazer referência a alguns e identificar expressões semelhantes no editorial d' $O$ Globo como meio de amenizar o erro.

No dia 30 de março de 2014, a Folha de S. Paulo, em seu editorial, trazia o seguinte trecho: "é fácil, até pusilânime, porém, condenar agora os responsáveis pelas opções daqueles tempos, exercidas em condições tão mais adversas e angustiosas que as atuais". De acordo com a publicação, os defensores do regime militar, à época, "agiram como lhes pareceu melhor ou inevitável naquelas circunstâncias". O texto defende também que repúdio ao regime é merecido, mas que nem todas as críticas têm fundamento. Sete meses após a publicação do editorial do jornal $O$ Globo analisado por nós, a Folha de S. Paulo se utiliza dos mesmos recursos para amenizar o "erro" cometido: "aos olhos de hoje, apoiar a ditadura militar foi um erro, mas as opções de então se deram em condições bem mais adversas que as atuais".

\section{Conclusões}

Neste ano, o golpe militar de 1964 completa 50 anos. De algum modo, ainda estamos vivendo os resquícios daquele período. Os estudos da Análise do Discurso podem ajudar a reduzir o índice de "desorientação" no qual boa parte do público leitor está inserida. Para as elites, é importante que a massa continue desorientada para que os discursos veiculados por meio da mídia possam surtir os efeitos buscados ${ }^{13}$.

Considerando os dois períodos analisados (época do golpe de 1964 e época das manifestações de junho), temos que o público leitor de 2013 encontrava-se mais orientado do que a grande massa que apoiou o golpe militar de 1964.

A mídia reconhece que atualmente o público leitor tem mais acesso à informação. Negar o que está presente em documentos acessíveis à massa é ser taxado explicitamente de uma entidade mentirosa. Como vimos, diante dos fatos, uma das alternativas encontradas por alguns jornais foi a confissão de culpa pelo apoio ao golpe. Mesmo com tal confissão, é de suma importância que o público leitor esteja atento às estratégias de manipulação e persuasão da mídia. Chomsky sabe da importância da mídia e faz um alerta sobre o seu papel na política contemporânea.

Considerando o papel que a mídia ocupa na política contemporânea, somos obrigados a perguntar: em que tipo de mundo e de sociedade queremos viver e, sobretudo, em que espécie de democracia estamos pensando quando desejamos que essa sociedade seja democrática? (CHOMSKY, 2013, p. 9)

Acreditamos, então, que a Análise Crítica de Discurso pode nos ajudar a compreender melhor as diversas formas de manipulação em discursos políticos que ocorrem nos veículos

\footnotetext{
${ }^{13}$ Não utilizamos o termo "massa" como um grupo amorfo, homogeneizado e passivo. Assim como Fairclough (2013), aceitamos a possibilidade de interpelação inconsciente dos sujeitos do discurso. O agente-sujeito é uma posição situada entre a determinação estrutural e a agência consciente. Ao mesmo tempo em que sofre uma determinação inconsciente, ele trabalha sobre as estruturas, a fim de modificá-las conscientemente. É como se a estrutura estivesse em constante risco material em função de práticas cotidianas de agentes conscientes
} 
midiáticos. Manipular pessoas envolve manipular suas mentes, ou seja, as crenças das pessoas, tais como seus conhecimentos, suas opiniões e suas ideologias, os quais por sua vez controlam suas ações (DIJK, 2008, p. 240). É papel do analista crítico do discurso atentar para essas formas de manipulação.

\section{Referências}

CHARAUDEAU, Patrick. O discurso propagandista : uma tipologia. in Machado, Ida Lucia \& Mello, Renato, Análises do Discurso Hoje, vol. 3. Rio de Janeiro : Nova Fronteira (Lucerna) 2010, p.57-78, 2010.

CHOMSKY, Noam. Mídia, propaganda política e manipulação. São Paulo: Editora WMF Martins Fontes, 2013.

DIJK, Teun A. van. Discurso e Contexto: Uma abordagem sociocognitiva. São Paulo: Contexto, 2012.

Discurso e Poder. São Paulo: Contexto, 2008.

FAIRCLOUGH, Norman. Discurso e Mudança Social. Brasília: Editora UnB, 2008.

2003.

N. Analysing Discourse. Textual analysis for social research. Londres: Routledge,

McQUAIL, Denis. McQuail's reader in mass communication theory. Sage, London, 2002. 


\section{Anexos}

\section{Apoio editorial ao golpe de 64 foi um erro}

A consciência não é de hoje, vem de discussões internas de anos, em que as Organizações Globo concluíram que, à luz da História, o apoio se constituiu um equívoco por O Globo

31/08/2013 17:00 / Atualizado 31/08/2013 17:33

RIO - Desde as manifestações de junho, um coro voltou às ruas: “A verdade é dura, a Globo apoiou a ditadura". De fato, trata-se de uma verdade, e, também de fato, de uma verdade dura. Já há muitos anos, em discussões internas, as Organizações Globo reconhecem que, à luz da História, esse apoio foi um erro.

Há alguns meses, quando o Memória estava sendo estruturado, decidiu-se que ele seria uma excelente oportunidade para tornar pública essa avaliação interna. E um texto com o reconhecimento desse erro foi escrito para ser publicado quando o site ficasse pronto.

Não lamentamos que essa publicação não tenha vindo antes da onda de manifestações, como teria sido possível. Porque as ruas nos deram ainda mais certeza de que a avaliação que se fazia internamente era correta e que o reconhecimento do erro, necessário.

Governos e instituições têm, de alguma forma, que responder ao clamor das ruas.

De nossa parte, é o que fazemos agora, reafirmando nosso incondicional e perene apego aos valores democráticos, ao reproduzir nesta página a íntegra do texto sobre o tema que está no Memória, a partir de hoje no ar:

\section{4}

"Diante de qualquer reportagem ou editorial que lhes desagrade, é frequente que aqueles que se sintam contrariados lembrem que O GLOBO apoiou editorialmente o golpe militar de 1964.

A lembrança é sempre um incômodo para o jornal, mas não há como refutá-la. É História. O GLOBO, de fato, à época, concordou com a intervenção dos militares, ao lado de outros grandes jornais, como "O Estado de S.Paulo", "Folha de S. Paulo", "Jornal do Brasil" e o "Correio da Manhã", para citar apenas alguns. Fez o mesmo parcela importante da população, um apoio expresso em manifestações e passeatas organizadas em Rio, São Paulo e outras capitais.

Naqueles instantes, justificavam a intervenção dos militares pelo temor de um outro golpe, a ser desfechado pelo presidente João Goulart, com amplo apoio de sindicatos — Jango era criticado por tentar instalar uma "república sindical" - e de alguns segmentos das Forças Armadas.

Na noite de 31 de março de 1964, por sinal, O GLOBO foi invadido por fuzileiros navais comandados pelo Almirante Cândido Aragão, do "dispositivo militar" de Jango, como se dizia na época. O jornal não pôde circular em $1^{\circ}$ de abril. Sairia no dia seguinte, 2, quintafeira, com o editorial impedido de ser impresso pelo almirante, "A decisão da Pátria". $\mathrm{Na}$ primeira página, um novo editorial: "Ressurge a Democracia".

A divisão ideológica do mundo na Guerra Fria, entre Leste e Oeste, comunistas e capitalistas, se reproduzia, em maior ou menor medida, em cada país. No Brasil, ela era aguçada e aprofundada pela radicalização de João Goulart, iniciada tão logo conseguiu, em janeiro de 1963, por meio de plebiscito, revogar o parlamentarismo, a saída negociada para que ele, vice, pudesse assumir na renúncia do presidente Jânio Quadros. Obteve, então, os poderes plenos do presidencialismo. Transferir parcela substancial do poder do Executivo ao Congresso havia 
sido condição exigida pelos militares para a posse de Jango, um dos herdeiros do trabalhismo varguista. Naquele tempo, votava-se no vice-presidente separadamente. Daí o resultado de uma combinação ideológica contraditória e fonte permanente de tensões: o presidente da UDN e o vice do PTB. A renúncia de Jânio acendeu o rastilho da crise institucional.

A situação política da época se radicalizou, principalmente quando Jango e os militares mais próximos a ele ameaçavam atropelar Congresso e Justiça para fazer reformas de "base" "na lei ou na marra". Os quartéis ficaram intoxicados com a luta política, à esquerda e à direita. Veio, então, o movimento dos sargentos, liderado por marinheiros - Cabo Ancelmo à frente - , a hierarquia militar começou a ser quebrada e o oficialato reagiu.

Naquele contexto, o golpe, chamado de "Revolução", termo adotado pelo GLOBO durante muito tempo, era visto pelo jornal como a única alternativa para manter no Brasil uma democracia. Os militares prometiam uma intervenção passageira, cirúrgica. Na justificativa das Forças Armadas para a sua intervenção, ultrapassado o perigo de um golpe à esquerda, o poder voltaria aos civis. Tanto que, como prometido, foram mantidas, num primeiro momento, as eleições presidenciais de 1966.

O desenrolar da "revolução" é conhecido. Não houve as eleições. Os militares ficaram no poder 21 anos, até saírem em 1985, com a posse de José Sarney, vice do presidente Tancredo Neves, eleito ainda pelo voto indireto, falecido antes de receber a faixa.

No ano em que o movimento dos militares completou duas décadas, em 1984, Roberto Marinho publicou editorial assinado na primeira página. Trata-se de um documento revelador. Nele, ressaltava a atitude de Geisel, em 13 de outubro de 1978, que extinguiu todos os atos institucionais, o principal deles o AI5, restabeleceu o habeas corpus e a independência da magistratura e revogou o Decreto-Lei 477, base das intervenções do regime no meio universitário.

Destacava também os avanços econômicos obtidos naqueles vinte anos, mas, ao justificar sua adesão aos militares em 1964, deixava clara a sua crença de que a intervenção fora imprescindível para a manutenção da democracia e, depois, para conter a irrupção da guerrilha urbana. E, ainda, revelava que a relação de apoio editorial ao regime, embora duradoura, não fora todo o tempo tranquila. Nas palavras dele: "Temos permanecido fiéis aos seus objetivos [da revolução], embora conflitando em várias oportunidades com aqueles que pretenderam assumir a autoria do processo revolucionário, esquecendo-se de que os acontecimentos se iniciaram, como reconheceu o marechal Costa e Silva, 'por exigência inelutável do povo brasileiro'. Sem povo, não haveria revolução, mas apenas um 'pronunciamento' ou 'golpe', com o qual não estaríamos solidários."

Não eram palavras vazias. Em todas as encruzilhadas institucionais por que passou o país no período em que esteve à frente do jornal, Roberto Marinho sempre esteve ao lado da legalidade. Cobrou de Getúlio uma constituinte que institucionalizasse a Revolução de 30, foi contra o Estado Novo, apoiou com vigor a Constituição de 1946 e defendeu a posse de Juscelino Kubistchek em 1955, quando esta fora questionada por setores civis e militares.

Durante a ditadura de 1964, sempre se posicionou com firmeza contra a perseguição a jornalistas de esquerda: como é notório, fez questão de abrigar muitos deles na redação do GLOBO. São muitos e conhecidos os depoimentos que dão conta de que ele fazia questão de acompanhar funcionários de O GLOBO chamados a depor: acompanhava-os pessoalmente para evitar que desaparecessem. Instado algumas vezes a dar a lista dos "comunistas" que trabalhavam no jornal, sempre se negou, de maneira desafiadora.

Ficou famosa a sua frase ao general Juracy Magalhães, ministro da Justiça do presidente Castello Branco: "Cuide de seus comunistas, que eu cuido dos meus". Nos vinte anos durante os quais a ditadura perdurou, O GLOBO, nos períodos agudos de crise, mesmo sem retirar o 
apoio aos militares, sempre cobrou deles o restabelecimento, no menor prazo possível, da normalidade democrática.

Contextos históricos são necessários na análise do posicionamento de pessoas e instituições, mais ainda em rupturas institucionais. A História não é apenas uma descrição de fatos, que se sucedem uns aos outros. Ela é o mais poderoso instrumento de que o homem dispõe para seguir com segurança rumo ao futuro: aprende-se com os erros cometidos e se enriquece ao reconhecê-los.

Os homens e as instituições que viveram 1964 são, há muito, História, e devem ser entendidos nessa perspectiva. O GLOBO não tem dúvidas de que o apoio a 1964 pareceu aos que dirigiam o jornal e viveram aquele momento a atitude certa, visando ao bem do país.

À luz da História, contudo, não há por que não reconhecer, hoje, explicitamente, que o apoio foi um erro, assim como equivocadas foram outras decisões editoriais do período que decorreram desse desacerto original. A democracia é um valor absoluto. E, quando em risco, ela só pode ser salva por si mesma."

\section{2 de abril de 1964}

\section{"Ressurge a Democracia"}

Vive a Nação dias gloriosos. Porque souberam unir-se todos os patriotas, independentemente de vinculações políticas, simpatias ou opinião sobre problemas isolados, para salvar o que é essencial: a democracia, a lei e a ordem. Graças à decisão e ao heroísmo das Forças Armadas, que obedientes a seus chefes demonstraram a falta de visão dos que tentavam destruir a hierarquia e a disciplina, o Brasil livrou-se do Governo irresponsável, que insistia em arrastálo para rumos contrários à sua vocação e tradições.Como dizíamos, no editorial de anteontem, a legalidade não poderia ser a garantia da subversão, a escora dos agitadores, o anteparo da desordem. Em nome da legalidade, não seria legítimo admitir o assassínio das instituiçõos, como se vinha fazendo, diante da Nação horrorizada.

Agora, o Congresso dará o remédio constitucional à situação existente, para que o País continue sua marcha em direção a seu grande destino, sem que os direitos individuais sejam afetados, sem que as liberdades públicas desapareçam, sem que o poder do Estado volte a ser usado em favor da desordem, da indisciplina e de tudo aquilo que nos estava a levar à anarquia e ao comunismo.

Poderemos, desde hoje, encarar o futuro confiantemente, certos, enfim, de que todos os nossos problemas terão soluções, pois os negócios públicos não mais serão geridos com máfé, demagogia e insensatez.

Salvos da comunização que celeremente se preparava, os brasileiros devem agradecer aos bravos militares, que os protegeram de seus inimigos. Devemos felicitar-nos porque as Forças Armadas, fiéis ao dispositivo constitucional que as obriga a defender a Pátria e a garantir os poderes constitucionais, a lei e a ordem, não confundiram a sua relevante missão com a servil obediência ao Chefe de apenas um daqueles poderes, o Executivo. 
As Forças Armadas, diz o Art. 176 da Carta Magna, "são instituições permanentes, organizadas com base na hierarquia e na disciplina, sob a autoridade do Presidente da República E DENTRO DOS LIMITES DA LEI."

No momento em que o Sr. João Goulart ignorou a hierarquia e desprezou a disciplina de um dos ramos das Forças Armadas, a Marinha de Guerra, saiu dos limites da lei, perdendo, conseqüentemente, o direito a ser considerado como um símbolo da legalidade, assim como as condições indispensáveis à Chefia da Nação e ao Comando das corporações militares. Sua presença e suas palavras na reunião realizada no Automóvel Clube, vincularam-no, definitivamente, aos adversários da democracia e da lei.

Atendendo aos anseios nacionais, de paz, tranqüilidade e progresso, impossibilitados, nos últimos tempos, pela ação subversiva orientada pelo Palácio do Planalto, as Forças Armadas chamaram a si a tarefa de restaurar a Nação na integridade de seus direitos, livrando-os do amargo fim que lhe estava reservado pelos vermelhos que haviam envolvido o Executivo Federal.

Este não foi um movimento partidário. Dele participaram todos os setores conscientes da vida política brasileira, pois a ninguém escapava o significado das manobras presidenciais. Aliaram-se os mais ilustres líderes políticos, os mais respeitados Governadores, com o mesmo intuito redentor que animou as Forças Armadas. Era a sorte da democracia no Brasil que estava em jogo.

A esses líderes civis devemos, igualmente, externar a gratidão de nosso povo. Mas, por isto que nacional, na mais ampla acepção da palavra, o movimento vitorioso não pertence a ninguém. É da Pátria, do Povo e do Regime. Não foi contra qualquer reivindicação popular, contra qualquer idéia que, enquadrada dentro dos princípios constitucionais, objetive o bem do povo e o progresso do País.

Se os banidos, para intrigarem os brasileiros com seus líderes e com os chefes militares, afirmarem o contrário, estarão mentindo, estarão, como sempre, procurando engodar as massas trabalhadoras, que não lhes devem dar ouvidos. Confiamos em que o Congresso votará, rapidamente, as medidas reclamadas para que se inicie no Brasil uma época de justiça e harmonia social. Mais uma vez, o povo brasileiro foi socorrido pela Providência Divina, que lhe permitiu superar a grave crise, sem maiores sofrimentos e luto. Sejamos dignos de tão grande favor."

\section{Editorial}

\section{Folha de São Paulo}

30 de março de 2014

O regime militar (1964-1985) tem sido alvo de merecido e generalizado repúdio. Uma consolidação da democracia, nas últimas três décadas, torna ainda mais notória a violência que ditadura representou. 
Violência contra a população, privada do direito elementar ao autogoverno. E violência contra opositores, perseguidos por mero delito de opinião, quando não presos ilegalmente e torturados, sobretudo no período de combate à guerrilha, entre 1969 e 1974.

Aquela foi uma era de feroz confronto entre dois modelos de sociedade - o socialismo revolucionário e a economia de mercado. Polarizadas, como forças engajadas em cada sabotavam as fórmulas intermediárias e a própria confiança na solução pacífica das divergências, essencial à democracia representativa.

A direita e a parte dos liberais violaram a ordem constitucional em 1964 e impuseram um governo ilegítimo. Alegavam fazer contrarrevolução, destinada a impedir seus adversários de implantar ditadura ainda pior, mas com isso detiveram um impulso de mudança e participação social.

Parte da Esquerda forçou os limites da legalidade na urgência de realizar, no começo dos Anos 60, reformas que tinham muito de demagógico. Logo após 1964, quando a ditadura ainda se continha em certas balizas, grupos militarizados desencadearam uma luta armada dedicada a instalar, precisamente como eram acusados pelos adversários, uma ditadura comunista no país.

As responsabilidades pela espiral de violência se distribuem, assim, pelos dois extremos, mas não igualmente: a maior parcela de culpa cabe ao lado que impôs uma lei do mais forte, e o pior crime foi cometido por aqueles que fizeram da tortura uma política clandestina de Estado.

Isso não significa que todas as Criticas à ditadura tenham fundamento. Realizações de cunho econômico e estrutural desmentem a noção de um período de estagnação ou retrocesso.

Em 20 Anos, a economia cresceu três vezes e meia. O produto nacional per capita mais que dobrou. A infraestrutura de transportes e comunicações se ampliou e se modernizou. A Inflação, na Maior Parte do Tempo, manteve-se baixa.

Todas as camadas sociais progrediram, embora de forma desigual, o que acentuou a iniquidade. Mesmo assim, um dado social revelador como a taxa de mortalidade infantil a cada mil nascimentos, que era de 116 em 1965, caiu a 63 em 1985 (e melhorou cada vez mais até chegar a 15,3 em 2011).

No atendimento a demandas de saúde e educação, contudo, a ditadura ficou aquém de seu desempenho econômico.

Sob um importante aspecto, 1964 não marca uma ruptura, mas o prosseguimento de um rumo anterior. Os governos militares consolidaram uma política de substituição de importações, via proteção tarifária, que vinha sendo a principal alavanca da industrialização induzida Pelo Estado e que permitiu, nos anos 70, instalar uma pesada indústria no país.

A Economia se diversificou e a sociedade não apenas se urbanizou (metade dos brasileiros vivia em cidades em 1964; duas décadas depois, eram mais de 70\%) mas também se tornou mais dinâmica e complexa. Metrópoles cresceram de modo desordenado, ensejando problemas agudos de circulação e segurança.

$\mathrm{O}$ regime passou por fases diferentes, desde o surto repressivo do primeiro ano e o interregno moderado que precedeu a ditadura desabrida, brutal, da passagem da década, até uma demorada abertura política, iniciada dez anos antes de sua extinção formal, em 1985. 
As crises do petróleo e da dívida externa desencadearam desarranjos na economia, logo traduzidos em perda de apoio, inclusive eleitoral. O regime se tornara estreito para uma sociedade que não cabia mais em seus limites. Dissolveu-se numa transição negociada da qual a anistia recíproca foi o alicerce.

Às vezes se cobra, desta Folha, ter apoiado a ditadura durante a primeira metade de sua vigência, um dos veículos mais críticos na metade seguinte. Não há dúvida de que, aos olhos de hoje, aquele apoio foi um erro.

Este jornal deveria ter rechaçado toda violência, de ambos os lados, mantendo-se um defensor intransigente da democracia e das liberdades individuais.

É fácil, até pusilânime, porém, condenar ágora os responsáveis pelas opções daqueles tempos, exercidas em condições tão mais adversas e angustiosas que as atuais. Agiram como lhes pareceu melhor ou inevitável naquelas circunstâncias.

Visto em perspectiva, o período foi um longo e doloroso aprendizado para todos os que atuam no espaço público, até atingirem a atual maturidade no respeito comum às regras e na renúncia à violência como forma de lutar por ideias. Que continue sendo assim. 